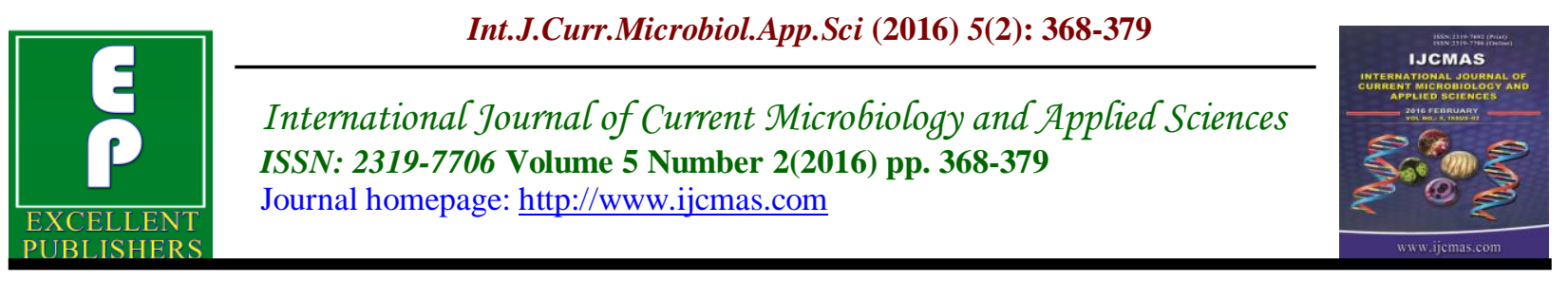

Original Research Article

doi: http://dx.doi.org/10.20546/ijcmas.2016.502.042

\title{
Biochemical Characterization of Sugarcane Varieties Cultivated in Benin
}

\author{
O. S. Ekpélikpézé ${ }^{1}$, A. Dansi ${ }^{1 *}$, C. Agbangla ${ }^{2}$, A. Akoegninou ${ }^{3}$ and A. Sanni ${ }^{4}$ \\ ${ }^{1}$ Laboratory of Biotechnology, Genetic Resources and Plant and \\ Animal Breeding (BIORAVE), Faculty of Sciences and Technology of Dassa, \\ Polytechnic University of Abomey, BP 14 Dassa, Benin \\ ${ }^{2}$ Laboratory of Genetics and Biotechnology, Faculty of Sciences and Technology \\ (FAST),University of Abomey-Calavi (UAC), Abomey-Calavi, 01BP526, Cotonou, Benin \\ ${ }^{3}$ National Herbarium, Department of Botany and Plant Biology, Faculty of Sciences and \\ Technology (FAST), University of Abomey-Calavi (UAC), BP 526, Cotonou, Benin \\ ${ }^{4}$ Laboratory of Biochemistry and Molecular Biology, Faculty of Sciences and Technology \\ (FAST), University of Abomey-Calavi (UAC), P.O. Box 526 Cotonou, Benin \\ *Corresponding author
}

\begin{abstract}
A B S T R A C T
Keywords

Benin,

Saccharum

officinarum,

Sugarcane,

Technological quality, Elite varieties

Article Info

Accepted:

18 January 2016

Available Online:

10, February 2016

Sugarcane plays a great role in rural community for food security and income generation. However the potentials of the different sugarcane varieties grown in Benin are still unknown and the crop receives little attention from the national research. In this study,42 sugarcane landraces were collected in Benin and analyzed for their technological qualities such as Brix, Pol, purity of the juice, juice content, fiber content, phosphate, saccharose and sugar content. Among the different parameters analyzed, phosphate content, sugar reducer and fiber content presented the highest variability with 57,$7 ; 1,59$ and 13,2 as average means. Highly positive and significante correlation were observed between saccharose content and parameters like brix, sugar content, Poland juice purity .In contrast, juice content is negatively correlated with the Brix content, the Pol\%, the saccharose, the sugar and the fiber content. Based on results of the study, 10 elite varieties have been identified and can be promoted for sugar and juice production.
\end{abstract}

\section{Introduction}

Sugarcane is an important crop in tropical and sub-tropical regions and it is cultivated worldwide on nearly 23 million hectares with an annual production averaging 1.9 million of tons in 2013 (FAOSTAT, 2015).
Rich in saccharose, raw sugarcane juice is energetic, stimulant and highly nutritive. The juice is diuretic and rich in vitamins B1, B2, B3 and C, calcium, phosphorus, iron, etc. and is recommended either diluted or 
not to convalescents, children and old peoples (Archimède et al., 2011; Nusrat et al., 2014). The bagasse, fibrous residue resulting from the first step of sugar extraction through grinding, is the most valorized sugarcane product. In fact, bagasse is a source of natural and renewable source of energy. Ash from sugar trash contains several elements including, among others, silica, iron, alumina, calcium, magnesium and potassium that enables its use in agriculture as calcic amendment or phosphoric and potassic fertilizer for improvementof soil fertility and soil's water retention capacity (Nusrat et al., 2014). Bagasse is also used in the processing of several other products such as paper, cartoon, resin, solvent, etc. Sugarcane is a source of bio-ethanolused as bio-fuel. This contributes to the reduction of greenhouse gases and therefore to the protection of the environment (Singh et al., 2008). Treacle is one of the by-products obtained in the process of sugar extraction. It is used in the production of various microorganisms such as bacteria, yeast etc. and in many other products including acetic acid, citric acid (Archimède et al., 2011), production of plasticizers, protective or adhesive coat in cosmetic (Singh et al., 2008). Cheap vine, obtained from the distillation of treacle in the process of alcohol production is used in agriculture as fertilizer.

Despite the food, health, agronomic, industrial, environmental and economic importance of sugarcane, little is known on the chemical composition of its different landraces in Benin. This lack of information prevents the population from taking advantage of the potential of sugarcane. Our study aimed at identifying the biochemical composition of sugarcane varieties cultivated in Benin in order to identify the best promising varieties for industrial production.

\section{Materials and Methods}

The plant material consisted of 38 sugarcane accessions collected from various regions in Benin and 4 improved varieties exploited by the Chinese sugar industry named Complant Bénin (SuCoBe) located in the district of Savè (central Benin). These 42 accessions were maintained as field collection at the lowland experimental field of the Faculty of Science and Technology (FAST) based at Djèrègbé, a village located in South-Eastern Benin between $6^{\circ} 22$ and $6^{\circ} 28 \mathrm{~N}$ and $2^{\circ} 43 \mathrm{E}$. The experimental site has a sub-equatorial climate characterized by four seasons (two dry and two rainy) with an average annual rainfall of $1100 \mathrm{~mm}$. The average annual temperature is $27^{\circ} \mathrm{C}$ and the relative humidity is relatively high (Akoègninou et al., 2006). The 42 accessions were submitted to the determination of biochemical traits thatare Brix \%, Pol \%, Juice \%, Fiber \%, Phosphate $\%$, and apparent purity of the juice (PA). From each variety, three stems were manually cut using a machete. The stems were cut close to the ground and the leaves were removed up to the top. The operation was done either in the evening or early in the morning (around $6 \mathrm{am}$ ) of the day that the analyses were to be performed. The stems were cut in small pieces, labelled and bagged before the transportation to the biochemical laboratory.

\section{Determination of Biochemical Content of Sugarcane Varieties}

Sugarcane samples were ground using an electric grinder (Jeffco food and fodder grinder, model 265B Size10, Serial L1710) andthe pulp obtained was homogenized. A sample of $2000 \mathrm{~g}$ was taken and the raw juice was separated from bagasse using a hydraulic press. The Brix was determined from the raw juice using a Briximeter. A 
part of the raw juice was clarified after adding hydroxide acetate (II) or Horne salt to $2.5 \mathrm{~g}$ of non-diluted juice following Abdelmahmoud et al., (2012). After the filtration of the juice on filter paper, the Pol\% was read using a polarimeter. Schmidt's table was used to determine the Pol\% of the juice based on the read Pol. The apparent purity (PA) corresponds to the rate of the Pol in the Brix. Saccharine richness was determined by multiplying the Pol of the juice by the $\mathrm{k}$ read factor on the second table. The level of reducing sugar (glucose coefficient) was determined using Fehling test as followingTouré et al., (2013).

- Apparent purity of the juice (PA) :

PA $=\frac{\text { Pol } \%}{\text { CorrectedBrix }} \times 100$

- Reducing sugar content (SR) :

$\mathbf{S R}=\frac{\text { Valueofs } \% \text { readonthecorrespondencetable }}{\mathbf{V}} \mathbf{x}$

$\mathbf{N}$ (with $\mathbf{N}=$ normality equal to 1 ).

Saccharine richness $(\mathrm{S} \%)$ :

$\mathbf{S} \%=(\mathbf{P}-\mathbf{P} ') \mathbf{x}_{\mathbf{K} 2}^{\mathbf{K} 1}$; with $\mathrm{K}_{1}$ and $\mathrm{K}_{2}$

depending on the Brix and temperature, respectively.

Sugar content :

Sucre \% canne =

[(RawjuicexSaccharose)+ (BagassexSugarof cane-trash)] massofthecane

Fiber content was determine by :

Cane fiber $\%=\frac{\text { bagassexFiberofcane-trash }}{\text { massofthecane }}$

The analysis of bagasse was essentially related to its moisture content using oven drying method, its Brix, Pol\% and fiber content.

Water content of the bagasse:

$\mathrm{H}_{2} \mathrm{O}=$ Brix of bagasse

$=$

[correctedBrix(bagassejuice+H2Ocane-trashe]-65,5]

100-correctedbagassebrix

pol\% of bagasse:

Pol \% of bagasse $=$ ObservedPol(260,73-observedbrix)(juice+H20+bagassebrix) 100.000

Bagasse fiber:Bagasse fiber= 100 - bagasse brix-moisture content of bagasse

\section{Data Analysis}

The data were analyzed using descriptive statistics (frequencies, range, mean, standard deviation and coefficient of variation) using SPAD 5.5 software. Pearson's coefficient of correlation was calculated to assess the relationship between the different biochemical variables using the same software. A multivariate analysis was also performed to examine the relationship between varieties. For this varieties were considered as individuals and biochemical characters as variables and adendrogramme was performed using Ward algorithm based on Euclidean distance and with Minitab 14.

\section{Results and Discussion}

Table 2 shows the minimum, the maximum, the mean and the standard deviation of each biochemical variable. Phosphorus, reducing sugar and fibers content showed wide range. Phosphorus content ranged from $27 \%$ to $100 \%$ with an average of $57.78 \%$. The reducing sugar content was $1.59 \%$ inaverage with a variation between 0.63 and $4.45 \%$. 
Fiber content ranged from 9.96 to $18.6 \%$ with an average of $13.27 \%$. Figure 1 presents in one hand the frequency of varieties having a mean higher than the overall man for Brix, sugar content, saccharose, apparent purity, Pol and phosphate and in other hand the proportion of varieties having a mean lower than the overall man for reducing sugar and fiber content. About $60.47 \%, 58.14 \%$ and $53.49 \%$ of the varieties had juice, apparent purity and phosphate mean higher than the mean calculated over all the varieties for each of these variables while (Figure 1) while the opposite was observed for $67.44 \%$ of the varieties for reducing sugar. Based on the percentage of varieties having biochemical compositions higher or lesser than the overall mean for each trait, 13 most promising varieties were identified. The identified varieties were composed of 4 accessions (R575, Co957, Co997, R573) collected from $\mathrm{SuCoBe}$, and 9 landraces collected from farmers in Benin and which include Aréké-Tourawa, Léké-vêê, IrékéOniandoudou, Léké-fèfè, Léké-vovo, Souclétchi-mamoui, Souclétin-hé, Yéké and Yéké-foufou. .

The dendrogramme grouped the varieties in four clusters (G1, G2, G3, G4) based on their similarities (Figure 2). G1 groups together 13 varieties characterized by high Brix, high Pol, high apparent purity and high saccharose. This group contained four varieties namely Co957, Co997, R573 and R575 cultivated by the sugar company SuCoBe and nine landraces (Table 4). Apart from Leké-vêê, all the varieties previously identified by the frequency and mean method were found in this group. Varieties of G1 can be considered as elite varieties based on their biochemical composition (Table 4). G2 assembles 13 varieties showing low saccharose, saccharine and reducing sugar content but high juice and water content (Table 4). 11 varieties, characterized by high apparent purity and saccharose content but low phosphate content, were found in the group G3 (Table 4 ). The group G4 contained only one variety characterized in one hand by low Brix, Pol and saccharose content and in the other hand with high juice showing that this variety has high moisture content (Table 4).

\section{Relation between Biochemical Traits}

Using the Pearson's coefficient of correlation, a positive and statistically significant association was found between saccharose and Brix content $(\mathrm{r}=0.93)$; saccharose and Pol\% ( $r=0.98)$; saccharose and sugar content $(\mathrm{r}=0.98)$ and between saccharose and apparent purity $(\mathrm{r}=0.65)$. Correlation between Brix and Pol\% $(\mathrm{r}=$ $0.92)$, Brix and sugar content $(r=0.89)$ and Brix and fiber content $(\mathrm{r}=0.70)$ was positive and significant (Table 5). However, association between juice content and Brix, Pol\%, saccharose, sugar and fiber content was negative with correlation coefficient of $0.72 ;-0.69 ;-0.69 ; \quad-0.58$ and -0.94 , respectively (Table 5).

\section{Relationship between Biochemical Traits and Stem Color}

Seven external stem colors were recorded in the collection. Black $(28.57 \%$ of the varieties), green $(23.81 \%$ of the varieties), red wine $(23.81 \%$ of the varieties) were the most represented color in the collection (Figure 3)The external stem color was heterogeneous within the group formed based on the biochemical traits. However, in the cluster G1, which grouped the elite varieties, the external stem colors were yellow, green and red wine and none of the variety had black stem color even though it was the predominant color. In the reference accessions, Co957 and Co997 had yellow external color and R573 and R575 had red wine and red stem color, respectively. 
Table.1 List of Varieties of Sugarcane (S. officinarum) used in the Study

\begin{tabular}{|c|c|c|c|c|}
\hline $\mathbf{N}^{\circ}$ & Vernacular name & Villages & Districts & Departments \\
\hline 1 & Accession Co957 & Gobé & Savè & Collines \\
\hline 2 & Accession Co997 & Gobé & Savè & Collines \\
\hline 3 & Accession R 575 & Gobé & Savè & Collines \\
\hline 4 & Accession R573 & Gobé & Savè & Collines \\
\hline 5 & Aléké Doudou & Parakou & Parakou & Borgou \\
\hline 6 & AlékéOlomiwé & Parakou & Parakou & Borgou \\
\hline 7 & ArékéTourawa & Agbo & Savè & Collines \\
\hline 8 & Arékébaki & Agbo & Savè & Collines \\
\hline 9 & Azéléké & Agbvokou I & Porto-Novo & Ouémé \\
\hline 10 & AzélékéHuinihuini & Agonvè & Lokossa & Mono \\
\hline 11 & Azélékévôvô & Djeffa & Sèmè-kpodji & Ouémé \\
\hline 12 & Azélékéyibo & Donkondji & Athiémé & Mono \\
\hline 13 & Dawéléké & Tanvè & Bopa & Mono \\
\hline 14 & GartinDombourou & Bocossi & Péhunco & Atakora \\
\hline 15 & GartinFonharoun & Bcossi & Péhunco & Atakora \\
\hline 16 & GartinWonka & Bocossi & Péhunco & Atakora \\
\hline 17 & Gbaglo & Bamè & Zangnanado & Zou \\
\hline 18 & Gnankaniguê & Pabegou & Copargo & Borgou \\
\hline 19 & Ipèokangaignonyé & Affongosso & Djougou & Donga \\
\hline 20 & Ipéokangaipègni & Affongosso & Djougou & Donga \\
\hline 21 & Ipèokangaipègni & Affongosso & Djougou & Donga \\
\hline 22 & Kantooma & Doguê & Bassila & Donga \\
\hline 23 & KaraiItchirè & Affongosso & Djougou & Donga \\
\hline 24 & KaraiSooriou & Toko-Toko & Djougou & Donga \\
\hline 25 & Karakoukpéto & Timba & Djougou & Donga \\
\hline 26 & Konakri & Aguinhoué & Grand popo & Mono \\
\hline 27 & LékéAkparon & Igbo-Idji & Pobè & Plateau \\
\hline 28 & Lékéfèfè & Djèrègbé & Sèmè-kpodji & Ouémé \\
\hline 29 & LékéMamoui & Djanglanmè & Grand Popo & Mono \\
\hline 30 & Lékévêê & Djanglanmè & Grand popo & Mono \\
\hline 31 & Lékévovo & Zouto & Djidja & Zou \\
\hline 32 & Lékéwéwé & Agbokou I & Porto-Novo & Ouémé \\
\hline 33 & Lékékoklodjonon & Ké & Dangbo & Ouémé \\
\hline 34 & Ogniguin & Onigbolo & Pobè & Plateau \\
\hline 35 & Okpasukéréfounfoun & Tchatchégou & Glazoué & Collines \\
\hline 36 & Okpasukérékpikpa & Tchatchégou & Glazoué & Collines \\
\hline 37 & Sèmèlékéwiwi & Bamè & Zangnanado & Zou \\
\hline 38 & Souclétchi Hé & Sèwokondji & Grand popo & Mono \\
\hline 39 & SouclétchiMamoui & Todoga & Lokossa & Mono \\
\hline 40 & Yéké & Géézi & Adjawèrè & Plateau \\
\hline 41 & YékéFonton & Goézi & Adjawèrè & Plateau \\
\hline 42 & Yékéfoufou & Okéoudou & Adjawèrè & Plateau \\
\hline
\end{tabular}


Table.2 Descriptive Analysis of the Biochemical Variables in the Sugar Collection

\begin{tabular}{lccccc}
\hline Variables (\%) & Minimum & Maximum & Mean & Standard deviation & CV (\%) \\
\hline Brix & 13.94 & 21.46 & 17.52 & 2.03 & 11.60 \\
Fiber & 9.96 & 18.60 & 13.27 & 2.00 & 15.07 \\
Juice & 60.75 & 77.82 & 72.17 & 3.93 & 5.44 \\
Phosphorus & 27.00 & 100.00 & 57.78 & 13.00 & 22.50 \\
Polarity (POL) & 10.31 & 17.62 & 14.08 & 2.06 & 14.67 \\
Apparent Purity & 65.05 & 86.83 & 80.16 & 4.71 & 5.88 \\
Reducingsugar & 0.63 & 4.45 & 1.59 & 0.71 & 44.61 \\
Saccharose & 10.33 & 17.96 & 14.21 & 2.07 & 14.59 \\
Sugar & 8.95 & 14.67 & 11.74 & 1.46 & 12.45 \\
\hline
\end{tabular}

Figure.1 Frequency of Varieties with Mean Higher than the Pooled Mean

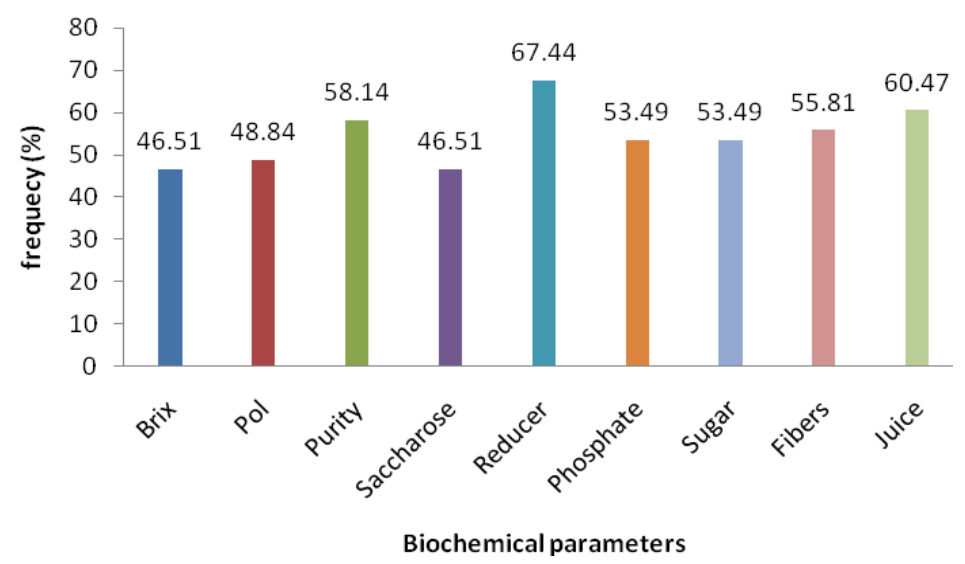

Figure.2 Dendrogram of S. officinarum Varieties based on Biochemical Composition

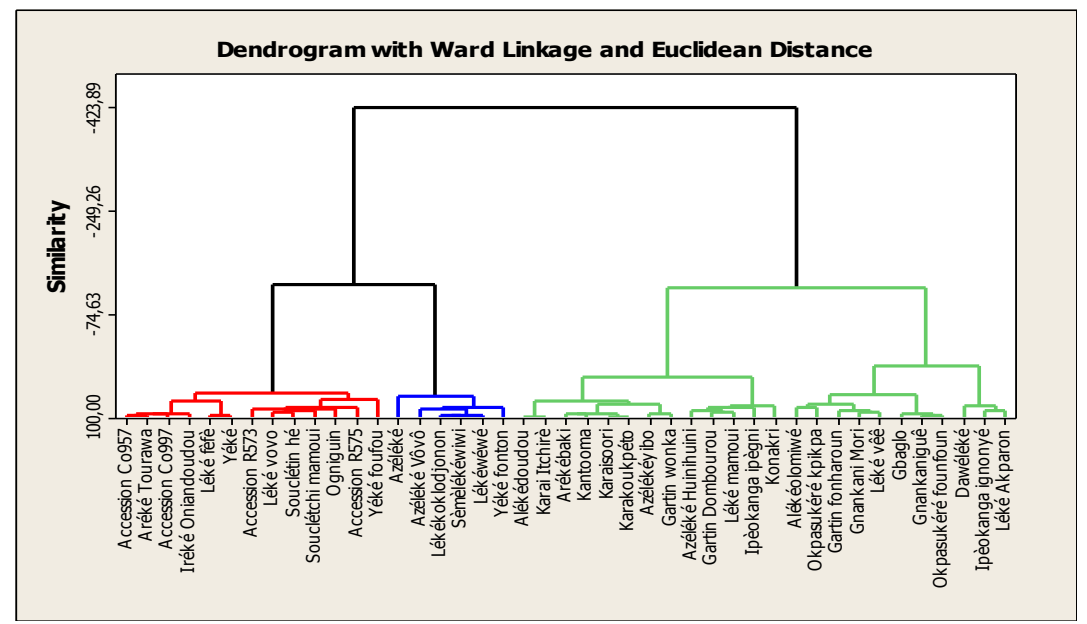


Table.3 Clasification and Identification of Promissing Sugarcane Varieties based on Biochemical Characters

\begin{tabular}{|c|c|c|c|c|c|c|c|c|c|c|}
\hline Noms Vernaculaires & Brix & Pol & Pureté & Sacch & Red & Phosp & Sucre & Fibres & Jus & $\mathbf{S}$ \\
\hline ArékéTourawa* & $\mathrm{X}$ & $\mathrm{x}$ & $\mathrm{X}$ & $\mathrm{x}$ & $\mathrm{x}$ & $\mathrm{x}$ & $\mathrm{x}$ & $\mathrm{X}$ & $\mathrm{x}$ & 9 \\
\hline Acc R575 & $\mathrm{x}$ & $\mathrm{x}$ & $\mathrm{x}$ & $\mathrm{x}$ & $\mathrm{x}$ & $\mathrm{x}$ & $\mathrm{x}$ & $\mathrm{x}$ & & 8 \\
\hline Lékévêê* & $\mathrm{x}$ & $\mathrm{x}$ & $\mathrm{x}$ & $\mathrm{x}$ & $\mathrm{x}$ & & $\mathrm{x}$ & $\mathrm{x}$ & $\mathrm{x}$ & 8 \\
\hline Acc Co957 & $\mathrm{x}$ & $\mathrm{x}$ & $\mathrm{x}$ & $\mathrm{x}$ & $\mathrm{x}$ & $\mathrm{X}$ & $\mathrm{X}$ & & & 7 \\
\hline Acc Co997 & $\mathrm{X}$ & $\mathrm{x}$ & $\mathrm{x}$ & $\mathrm{x}$ & $\mathrm{x}$ & $\mathrm{x}$ & $\mathrm{x}$ & & & 7 \\
\hline Acc R573 & $\mathrm{x}$ & $\mathrm{X}$ & $\mathrm{x}$ & $\mathrm{x}$ & $\mathrm{x}$ & $\mathrm{x}$ & $\mathrm{x}$ & & & 7 \\
\hline IrékéOniandoudou* & $\mathrm{x}$ & $\mathrm{x}$ & $\mathrm{x}$ & $\mathrm{x}$ & $\mathrm{x}$ & $\mathrm{x}$ & $\mathrm{x}$ & & & 7 \\
\hline Lékéfèfè* & $\mathrm{x}$ & $\mathrm{x}$ & $\mathrm{x}$ & $\mathrm{x}$ & & $\mathrm{x}$ & $\mathrm{x}$ & $\mathrm{x}$ & & 7 \\
\hline Lékévovo* & $\mathrm{x}$ & $\mathrm{x}$ & $\mathrm{x}$ & $\mathrm{x}$ & $\mathrm{x}$ & & $\mathrm{x}$ & & $\mathrm{x}$ & 7 \\
\hline Souclétchimamoui* & $\mathrm{x}$ & $\mathrm{X}$ & $\mathrm{x}$ & $\mathrm{x}$ & $\mathrm{x}$ & $\mathrm{x}$ & $\mathrm{x}$ & & & 7 \\
\hline Souclétin Hé * & $\mathrm{x}$ & $\mathrm{X}$ & $\mathrm{X}$ & $\mathrm{X}$ & $\mathrm{x}$ & & $\mathrm{x}$ & & $\mathrm{x}$ & 7 \\
\hline Yéké foufou* & $\mathrm{x}$ & $\mathrm{x}$ & $\mathrm{x}$ & $\mathrm{x}$ & $\mathrm{x}$ & $\mathrm{x}$ & $\mathrm{x}$ & & & 7 \\
\hline Yéké* & $\mathrm{x}$ & $\mathrm{x}$ & $\mathrm{x}$ & $\mathrm{x}$ & $\mathrm{x}$ & $\mathrm{x}$ & $\mathrm{x}$ & & & 7 \\
\hline LékéAkparon & & $\mathrm{X}$ & $\mathrm{x}$ & & $\mathrm{x}$ & & $\mathrm{x}$ & $\mathrm{x}$ & $\mathrm{x}$ & 6 \\
\hline Ipèokangaignonyé & $\mathrm{x}$ & & $\mathrm{x}$ & $\mathrm{X}$ & $\mathrm{x}$ & & $\mathrm{x}$ & & $\mathrm{X}$ & 6 \\
\hline Gartinfonharoun & $\mathrm{x}$ & & $\mathrm{X}$ & $\mathrm{x}$ & & & $\mathrm{x}$ & $\mathrm{x}$ & $\mathrm{X}$ & 6 \\
\hline Okpasukérékpikpa & $\mathrm{x}$ & $\mathrm{x}$ & & $\mathrm{X}$ & $\mathrm{x}$ & & $\mathrm{x}$ & & & 5 \\
\hline Okpasukéréfounfoun & $\mathrm{x}$ & $\mathrm{x}$ & $\mathrm{X}$ & $\mathrm{x}$ & & & $\mathrm{x}$ & & & 5 \\
\hline Ogniguin & $\mathrm{x}$ & $\mathrm{x}$ & & $\mathrm{X}$ & & $\mathrm{X}$ & $\mathrm{x}$ & & & 5 \\
\hline KaraiItchirè & & & $\mathrm{x}$ & & $\mathrm{x}$ & $\mathrm{x}$ & & $\mathrm{x}$ & $\mathrm{x}$ & 5 \\
\hline Gnankaniguê & $\mathrm{x}$ & $\mathrm{X}$ & $\mathrm{x}$ & $\mathrm{X}$ & & & $\mathrm{x}$ & & & 5 \\
\hline Gbaglo & $\mathrm{x}$ & $\mathrm{x}$ & $\mathrm{x}$ & $\mathrm{x}$ & & & $\mathrm{x}$ & & & 5 \\
\hline Alékédoudou & & & $\mathrm{X}$ & & $\mathrm{x}$ & $\mathrm{x}$ & & $\mathrm{x}$ & $\mathrm{X}$ & 5 \\
\hline Karakoukpéto & & & & & $\mathrm{x}$ & $\mathrm{x}$ & & $\mathrm{x}$ & $\mathrm{X}$ & 4 \\
\hline Karaisoori & & & & & $\mathrm{x}$ & $\mathrm{x}$ & & $\mathrm{x}$ & $\mathrm{x}$ & 4 \\
\hline Kantooma & & & & & $\mathrm{x}$ & $\mathrm{X}$ & & $\mathrm{x}$ & $\mathrm{X}$ & 4 \\
\hline Ipèokangaipègni & & & $\mathrm{x}$ & & $\mathrm{x}$ & & & $\mathrm{X}$ & $\mathrm{X}$ & 4 \\
\hline GnankaniMori & & $\mathrm{X}$ & $\mathrm{x}$ & & $\mathrm{x}$ & & $\mathrm{x}$ & & & 4 \\
\hline Gartinwonka & & & & & $\mathrm{x}$ & $\mathrm{X}$ & & $\mathrm{x}$ & $\mathrm{x}$ & 4 \\
\hline Azélékéyibo & & & & & $\mathrm{x}$ & $\mathrm{x}$ & & $\mathrm{x}$ & $\mathrm{x}$ & 4 \\
\hline Alékéolomiwé & & $\mathrm{X}$ & $\mathrm{x}$ & & $\mathrm{x}$ & & $\mathrm{x}$ & & & 4 \\
\hline Sèmèlékéwiwi & & & & & $\mathrm{x}$ & & & $\mathrm{x}$ & $\mathrm{x}$ & 3 \\
\hline Lékékoklodjonon & & & & & $\mathrm{x}$ & & & $\mathrm{x}$ & $\mathrm{x}$ & 3 \\
\hline Lékéwéwé & & & & & & $\mathrm{x}$ & & $\mathrm{X}$ & $\mathrm{x}$ & 3 \\
\hline Dawéléké & & & $\mathrm{x}$ & & & & & $\mathrm{x}$ & $\mathrm{X}$ & 3 \\
\hline AzélékéVôvô & & & & & & $\mathrm{x}$ & & $\mathrm{X}$ & $\mathrm{x}$ & 3 \\
\hline Azéléké & & & & & & $\mathrm{x}$ & & $\mathrm{x}$ & $\mathrm{x}$ & 3 \\
\hline Arékébaki & & & & & $\mathrm{x}$ & $\mathrm{x}$ & & $\mathrm{x}$ & $\mathrm{x}$ & 3 \\
\hline Lékémamoui & & & & & $\mathrm{x}$ & & & & $\mathrm{x}$ & 2 \\
\hline Konakri & & & & & & & & $\mathrm{X}$ & $\mathrm{x}$ & 2 \\
\hline GartinDombourou & & & & & & & & $\mathrm{X}$ & $\mathrm{x}$ & 2 \\
\hline AzélékéHuinihuini & & & & & & & & $\mathrm{x}$ & $\mathrm{X}$ & 2 \\
\hline Yékéfonton & & & & & & $\mathrm{X}$ & & & & 1 \\
\hline
\end{tabular}

NB : x: The criterion is met; Pol : polarity ; Sacch : saccharose ; Red : reducing sugar; Phosp : phosphorus 
Table.4 Distribution of the Sugarcane Varieties in the Different Groups

\begin{tabular}{|c|c|c|}
\hline Groups & Sugarcane varieties or accession & Characteristics \\
\hline $\begin{array}{l}\text { Groupe1* } \\
\text { (13 varieties) }\end{array}$ & $\begin{array}{l}\text { Co957 (J), Co997 (V), R573 (RV), R575 (R), } \\
\text { ArékéTourawa (RV), IrékéOniandoudou (V), } \\
\text { Lékéféfè (J), Léké-vovo (RV), Ogniguin(RV), } \\
\text { Souclétchi-mamoui (VF), Souclétin-Hé (J), Yéké } \\
\text { (V), Yékéfoufou (V). }\end{array}$ & $\begin{array}{l}\text { Varieties rich in } \\
\text { saccharose but with } \\
\text { low reducing sugar } \\
\text { content }\end{array}$ \\
\hline $\begin{array}{l}\text { Grot } \\
(13 \text { v }\end{array}$ & $\begin{array}{l}\text { Ipèokanga-ipègni (V), Gartin-Dombourou (J), } \\
\text { Ipèokanga-ipègni (J), Konakri (N), Lékémamoui } \\
\text { (V), Léké-vovo (RV), Léké-wéwé (V), Azéléké- } \\
\text { Huinihuini (RV), Alékédoudou (V), Arékébaki } \\
\text { (N), Azélékéyibo (N), Gartin-wonka (N), } \\
\text { Kantooma (N), Karai- Itchirè (N), Karaisoori } \\
\text { (RV), Karakoukpéto (N), }\end{array}$ & $\begin{array}{l}\text { os with low } \\
\text { ose and high } \\
\text { ontent }\end{array}$ \\
\hline $\begin{array}{l}\text { Group } 3 \\
\text { (11 varieties) }\end{array}$ & $\begin{array}{l}\text { Alékéolomiwé (V), Okpasukéré-kpikpa (RV), } \\
\text { Gartin-fonharoun (RV), Gnankani-Mori (N), } \\
\text { Léké-vêê (RV), Gbaglo (JR), Gnankaniguê (J), } \\
\text { Okpasukéré-founfoun (V), Dawéléké (V), } \\
\text { Ipèokanga-ignonyé (N), Léké-Akparon (V) }\end{array}$ & $\begin{array}{l}\text { Varieties averagely } \\
\text { rich in saccharose ; } \\
\text { High maturity rate }\end{array}$ \\
\hline $\begin{array}{l}\text { Group } 4 \\
\text { (6 varieties) }\end{array}$ & $\begin{array}{l}\text { Azéléké(N), Azéléké-vôvô (RV), Lékéwéwé } \\
(\mathrm{V}) \text {, Lékékoklodjonon (J), Sèmèlékéwiwi (N), } \\
\text { Yékéfonton (RV). }\end{array}$ & $\begin{array}{l}\text { Varieties with low } \\
\text { saccharose content, } \\
\text { high juice reducing } \\
\text { sugar content }\end{array}$ \\
\hline
\end{tabular}

Table.5 Correlation Between the Biochemical Traits

\begin{tabular}{llllllllll}
\hline & Brix & Pol\% & Purity & Sacch & Red & Phosp & Sugar & Fibers & Juice \\
\hline Brix & 1.00 & & & & & & & & \\
POL & $\mathbf{0 . 9 2}$ & 1.00 & & & & & & & \\
Purity & 0.33 & $\mathbf{0 . 6 7}$ & 1.00 & & & & & & \\
Sacch & $\mathbf{0 . 9 3}$ & $\mathbf{0 . 9 8}$ & $\mathbf{0 . 6 5}$ & 1.00 & & & & & \\
Red & 0.26 & 0.02 & -0.41 & 0.01 & 1.00 & & & & \\
Phosp & 0.14 & 0.02 & -0.24 & 0.02 & 0.23 & 1.00 & & & \\
Sugar & $\mathbf{0 . 8 9}$ & $\mathbf{0 . 9 8}$ & $\mathbf{0 . 6 8}$ & $\mathbf{0 . 9 8}$ & -0.04 & -0.03 & 1.00 & & \\
Fibers & $\mathbf{0 . 7 0}$ & $\mathbf{0 . 7 0}$ & 0.38 & $\mathbf{0 . 7 0}$ & 0.22 & 0.17 & $\mathbf{0 . 5 8}$ & 1.00 & \\
Juice & $\mathbf{- 0 . 7 2}$ & $\mathbf{- 0 . 6 9}$ & -0.31 & $\mathbf{- 0 . 6 9}$ & -0.32 & -0.26 & $\mathbf{- 0 . 5 8}$ & $\mathbf{- 0 . 9 4}$ & 1.00 \\
\hline NB :Sacch : saccharose $:$ Red : reducing sugar ; Phosp : Phosphorus $; \mathrm{P}>5 \%$. & & &
\end{tabular}


Figure.3 Proportion of Sugarcane Varieties per External Stem Color

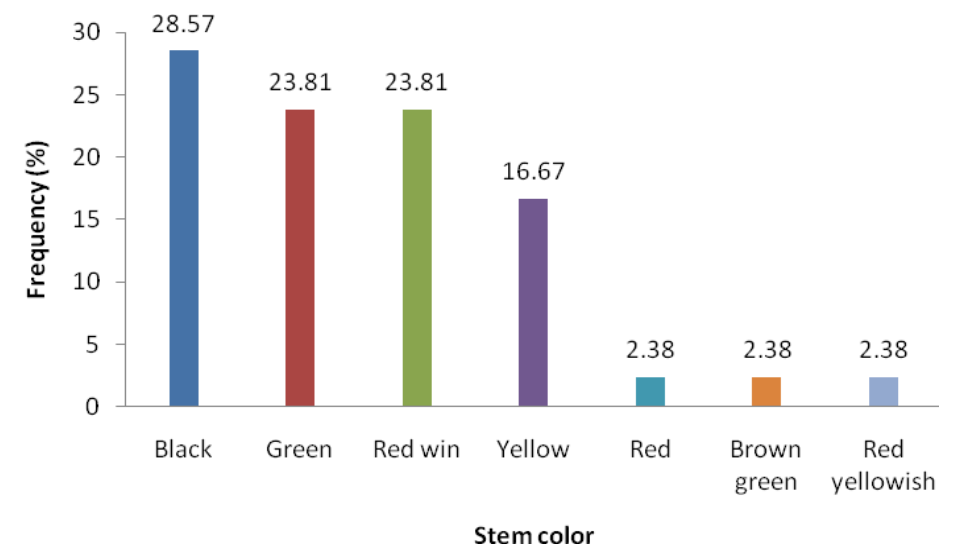

The success of a crop improvement programs requires a good understanding of genetic diversity in the collection (Muhammad et al., 2009). Agromorphological, molecular and biochemical characterization are generally used to assess genetic diversity in germplasm collection. Previous researches (Anshuman et al., 2003; Muhammad et al., 2009;

Abdelmahmoud and Ahmed, 2012) have revealed variability in sugarcane using biochemical characterization. Biochemical characterization is important to identify varieties with desirable technological traits to meet industrial requirements. In fact, sugar production companies require sugar meeting some standard in terms of biochemical composition and the quality of extraction of derived products (Suksombat and Mernkrathoke, 2005).

The percentage of juice, Brix value, Pol value, purity content and fiber are widely used as key biochemical element to assess the quality of sugarcane. In addition to these traits, the phosphate is an important variable that determines the richness in saccharine content. In fact, phosphate is needed by the crop for its growth and an increase in $\mathrm{P}_{2} \mathrm{O}_{5}$ positively affects sugar content in sugarcane
(Salazar et al., 2008). In our study, the variability observed in the majority of biochemical variables (phosphorus, reducing sugar, fibers, saccharose) revealed the presence of various chemiotypes in the sugarcane collection in Benin. Similar findings were reported by Abdelmahmoud and Ahmed (2012). Furthermore, Brix and juice content contribute more to the genetic variability (Silva, 2005). Similarly, Pol\% value and fiber content are key variable in the evaluation of genetic diversity in sugarcane collection (Touré et al., 2010).

The evaluation of Beninese sugarcane collection revealed that reducing sugar, phosphorus, fiber, saccharose, Pol\%, sugar and brix content were the most important traits discriminating the chemiotypes. However, apparent juice purity showed little variation among the varieties. Punia et al. (1983) made similar observation and reported that apparent purity had no significant contribution toward genetic diversity in sugarcane collection. Our results revealed that juice content showed little variation among varieties. Conversely, Silva et al., (2005) identified apparent purity as an important variable contributing to genetic diversity in sugarcane. Such a difference may be explained by the difference in the 
number of evaluated varieties, which are 42 in our study as compared to 129 in the study conducted by Silva et al., (2005).

For most of the variables and considering their means, the proportion of varieties was above $50 \%$. Only the proportion of varieties for Brix and saccharose were below 50. The identified elite varieties had their Brix, Pol, purity, saccharose, juice, phosphate mean higher than the mean over all the collection for each of the variable. In combination with these characters, only varieties with low fiber and reducing sugar were identified as elite varieties. In fact, varieties with low fiber content are characterized by a high sugar real extraction due to the richness in saccharine (Toure et al., 2010). An effective extraction actually corresponds to about $96 \%$ of the saccharose contained in the stem (Amrani, 2006). The use of low fiber content as an indicator of quality was confirmed by Gravois and Milligan (1992) who reported that the fiber is the dry and insoluble component in the extracted juice and it is inversely associated with the efficiency of grinding and juice extraction. Furthermore, Brix content is the most important index describing sugar content in a solution (Arzate, 2005).

This explained the positive and significant correlation observed between Brix and the saccharose content. The quality of the saccharose contained in the stem is then associated with the Brix. Thus, the mean of saccharose content that was $14.21 \%$ is closed to $15 \mathrm{~g} / 100 \mathrm{~g}$ of stem reported byTouré et al., (2010).According to the same author, the average value for juice, fiber and dry matter (Brix) for $100 \mathrm{~g}$ of stem were $87 \mathrm{~g}, 13 \mathrm{~g}$ and $17 \mathrm{~g}$, respectively. Similar values were recorded in our studies for these variables besides the juice content that was slightly lower than the reported value by Touré et al., (2010).
Reducing sugar content showed high variability as compared to the results obtained by Dias et al., (2010) while conducting similar study. Based on the mean value, varieties were potential varieties included all the four varieties of sugar production company "SuCoBe', namely R575, Co957, Co997 and R573 were identified as reference varieties. In addition, the following landraces were selected as elite varieties using the four varieties obtained from $\mathrm{SuCoBe}$ as reference since they showed similar biochemical compositions. In total, 10 sugarcane landraces viz. Aréké-Tourawa, Léké-vêê, Iréké-Oniandoudou, Léké-fèfè, Léké-vovo, Ogniguin, Souclétchi-mamoui, Souclétin-hé, Yéké and Yéké-foufou were considered as elite varieties. Among the elite varieties, Aréké-Tourawa ranked first and seemed to be more performant than the references. Hierarchical Ascendant Classification (HAC) confirmed the results of the classification based on means and clustered the elite varieties in one group G1 besides Léké-vêê.

Despite the predominance of varieties with black stem in the collection and the high productivity of these varieties (Ekpélikpézé et al., 2015), based on the biochemical characterization, none of them was identified as elite variety and all the elite varieties had colored stem. The elite varieties showed high potential for sugar production because of their high content of the stem in saccharose. In the HAC analysis, the varieties in the group G2 were characterized by low saccharose content and high juice content confirming the negative association between these two variables. This group presented an interesting character that was the low reducing sugar. This may be exploited in breeding programs. Conversely, varieties of group G4 showed low saccharose content and high reducing sugar content and presented therefore little 
potential in terms of their use in biochemical improvement programs of sugarcane.

Our study addressed only the biochemical traits of sugar. These traits may be limited in the ability to serve as effective basis for varietal selection (Abdelmahmoud and Ahmed, 2012). Combination of biochemical, molecular and agro-morphological characterization is required for an effective identification of varieties with high agronomic, phenotypic and biochemical potential. To this end, the assessment of the degree of association between agromorphological and biochemical traits will be of great interest (Abdelmahmoud and Ahmed, 2012). The identified varieties will then be promoted for industrial production.

In conclusion, the present study identified sugarcane landraces with high biochemical potential in Benin. The collection presented an important variability in terms of Brix, Pol\%, saccharose, reducing sugar, phosphate and fiber content hence indicating the great potential of the existing varieties for sugarcane improvement. While combining biochemical traits and external stem color, the most promising varieties were those with colored stem. Therefore, the stem color can be used as a primary indicator to identify varieties with good biochemical traits. However, in order to accurately group accessions and for the development of sugarcane core-collection in Benin for efficient use this study should be complemented with agro-morphological and molecular characterizations.

\section{Acknowledgments}

We thank the Laboratory of Biotechnology, genetic resources, and Animal and plant breeding (BIORAVE) for financial support and DrArletteAdjatin for technical assistance. We are also grateful to the staff of the Biochemical laboratory of SuCoBefor technical assistance and the farmers we met during the germplasm collection survey.

\section{References}

Abdelmahmoud O. A., Ahmed O. 2012. Correlation Pattern among Morphological and Biochemical Traits in Relation to Tillering Capacity in Sugarcane (SaccharumSpp). Academic Journal of Plant Sciences 5 (4): 119122.ISSN1995-8986. IDOSI Publications, 2012Doi: 10.5829/idosi.ajps.2012.5.4.1910

Akoégninou A., van der Burg W.J, van der Maesen. 2006. Flore Analytique de Bénin. BackhuysPublishers: Leiden; 1034.https://books.google.bj/books?i sbn $=9290814950$.

Amrani M. 2006. Détermination de la qualité dupain de sucre à partir des concentrationsdes sucres réducteurs. AJST, 7(1). 1 - 7.

AnshumanS., BhatnagarP.K., Khan A.Q., ShrotriaP.K. 2003. Association of quality characterswith cane and commercial cane sugar yield insugarcane. Sugar. Technol., 5(3): 197-198.

Archimède H., Xande X., Gourdine J.-L., Fanchone A., Alexandre G., Boval M., Coppry O., Arquet R., Fleury J., Regnier C., Renaudeau D. 2011. La canne à sucre et ses co-produits dans l'alimentation animale.

Arzate A. 2005. Extraction et raffinage du sucre decanne. Centre de recherche, dedéveloppement et de transfert techno-logique en acériculture (ACER), Saint-Norbert d'Arthabaska. 44 p.

Dias F.L.F., Rossetto R., Landell M.G.A., Mendes A. 2010.Silicon Amendment 
in the Productivity Of Four Sugarcane varieties in Brazil. Proc. Int. Soc. Sugar Cane Technol., Vol. 27.

Ekpélikpézé O.S., Loko Y.L., Adjatin A., Dansi A. 2015.Diversité variétale et évaluation participative des variétés de canne à sucre cultivées au Bénin. International Journal of Current Research in Biosciences and Plant Biology.In press.

FAOSTAT, 2015. FAO statistical database. Available online at URL.www.fao.org.

Gravois K.A.,Milligan S.B. 1992. Geneticrelationships between fibber andsugarcane yield components. Crop science. 32, 62 - 67.

Hoareau M. 1970. Utilisation de la presse hydraulique pour la détermination de la richesse saccharine de la canne à sucre. In : La canne à sucre. Fauconnier \&Bassereau. IRAT, Maisonneuve et Larose : 387-419.

Muhammad S.,Khan F.A. 2009.Genetic Diversity among Sugarcane Cultivars in Pakistan, AmericanEurasian J. Agric. and Environ. Sci., 6 (6): 730-736.

Nusrat H., Rani S., Siddiqui S., Shah Z., Zubair M.A. 2014. Impact of major farm inputs on productivity of sugarcane: a case study in tehsil kotaddu, punjab, Pakistan. Pakistan J. Agric. Res. 27(4): 1-6

Punia M.S., Chaudhary B.S.,HoodaR.S.1983. Genetic divergence in sugarcane. J. Agric.
Sci.,53(6): 434-436.

Salazar M.E., Sanchez M.A .2008. Concentraciónóptima de fósforo y evaluación delefec to residual en la producción y rendimiento de caña de azúcar. CINCAE (Centro de Investigación de la cañade Azúcardel Ecuador). Carta Informativa, 10(2): 8-11.

Silva C.M., Gonçalves-Vidigal M.C., FilhoP.S.V., ScapimC.A., DarosE.,SilvérioL. 2005. Geneticdiversity among sugarcane clones (Saccharum spp.) Acta Sci. Agron. Maringá.27:2315-319.

Singh V.K., Shukla A.K., Gill M.S., Sharma S.K., Tiwari K.N. 2008. Improving Sugarcane Productivity through Balanced Nutrition with Potassium, Sulphur, and Magnesium. Better Crops - India 17(2): 12- 15.

Suksombat W., Mernkrathoke P. 2005. Feeding of whole sugar cane to dairy cattle during the dry season. AsianAust. J. Anim. Sci. (18)3 : 345-349

Touré F.K. 2013.Evolution de la richesse, de la pureté et du coefficient glucosique de la Canne A Sucre de la coupe au broyage au complexe sucrier de Ferke 2 de la Sucaf-Ci.Agronomie Africaine 25 (1) : 1 - 12 (2013)

Touré F. K., Bohoussou, Koffi E., Agbo G.N.2010.Facteurs Lies Au Rendement Dans La RaffinerieDe Canne Du Perimetre Sucrier De Ferke len Côte D'ivoire. Agronomie Africaine 22 (1) : 85 - 95 (2010).

\section{How to cite this article:}

Ekpélikpézé, O. S., A. Dansi, C. Agbangla, A. Akoegninou and A. Sanni. 2016. Biochemical Characterization of Sugarcane Varieties Cultivated in Benin. Int.J.Curr.Microbiol.App.Sci.5(2): 368-379. doi: http://dx.doi.org/10.20546/ijcmas.2016.502.042 